\title{
Social housing in Italy: energy audit and dynamic simulation towards a nZEB policy
}

\author{
Alice Lorenzati, Ilaria Ballarini, Giovanna De Luca, Vincenzo Corrado \\ Politecnico di Torino, Turin, Italy
}

\begin{abstract}
The object of this paper is the analysis of a Social Housing building-type in the north of Italy, with the goal of reducing the energy consumption. The proposed methodology allows, once different hypotheses of energy refurbishment intervention on the existing building have been identified, to evaluate at the same time both technical and cost feasibility. The compliance with Italian nZEB requirements was also verified. The approach is based on the execution of detailed dynamic simulations (energy audits), combined with optimization, which allow to identify the set of retrofit actions that would determine the lowest global cost during the building lifecycle.
\end{abstract}

\section{Introduction}

The European Union policy is strongly focused on the energy saving and on the reduction of the current energy consumption. In this context the role of the existing building stock is increasingly important.

According to the last Italian census (carried out in 2011), the Italian residential building stock amounts to almost 12200000 buildings (about 84\% of the buildings on the Italian territory), with a total floor surface of about 2950 $\mathrm{Mm}^{2}$. Moreover, Italy spends 45.2 billion euros each year for thermal and electrical consumption in existing residential buildings (CRESME, 2014), corresponding to around 30 Mtoe (Eurostat statistics). This is mainly due to the fact that, about $26 \%$ of residential buildings were built before the Second World War, about $60 \%$ was built between 1945 and 1990, while only the remaining 14\% was built after 1991 (Corrado and Ballarini, 2016), and, therefore, after the first important Italian energy law, Law $n^{\circ} 10 / 1991$. The characteristics of the residential buildings in Italy and in the Piedmont Region were thoroughly investigated, regarding the building technologies, their thermal properties and the systems for the heating, cooling and DHW production (EEAP, 2014; Corrado and Ballarini, 2016).

The case study analysed in the following sections, was chosen among this typology of residential building, so as to be as representative as possible of the whole category.

\section{Energy audits and cost-optimal analysis of residential buildings}

The proposed procedure (a cost-optimal analysis combined with a detailed energy audit) was already developed by the authors (Corrado et al., 2017). It was used for the evaluation of the energy refurbishment strategies of school and office buildings (Corrado et al., 2017). In this research it was then applied to residential buildings.

On the one side, the evaluation of the energy performances of buildings are widespread; in Rhodes et al. (2015), the accuracies of the most common procedure are investigated. On the other side, the interest in the cost-optimality is still increasing and several methodologies are proposed in literature. For example, Dalla Mora et al. (2018), propose a methodology based on a life cycle cost assessment aimed to minimise the $\mathrm{CO}_{2}$ emissions (thermal properties, natural lighting, indoor air quality and acoustics are also considered as co-benefits). In Dodoo et al. (2017), cost-effectiveness of the energy refurbishment of a multi-storey residential building is evaluated considering the total and marginal investment costs of the measures, and also their net present value of total and marginal savings. Finally, Ascione et al. (2015), proposes to select the cost optimal solution considering also the minimum comfort level.

\section{Nearly Zero Energy Buildings requirements for residential buildings}

The requirements of nearly Zero Energy Buildings (nZEB) considered in the analysis are in conformity with the Interministerial Decree (I.D.) June $26^{\text {th }}, 2015$ and summarised in Table 1.

Table 1: nZEB requirements (I.D. June $26^{\text {th }}$, 2015).

\begin{tabular}{|c|c|}
\hline Parameter & Criteria \\
\hline$H_{\mathrm{T}}^{\prime}\left[\mathrm{W} / \mathrm{m}^{2} \mathrm{~K}\right]$ & $\begin{array}{l}H_{\mathrm{T}}^{\prime}<H_{\mathrm{T}, \text { limit }}^{\prime} \text { (depending on the building } \\
\text { compactness ratio and the climatic zone) }\end{array}$ \\
\hline$A_{\mathrm{sol}, \mathrm{sum}} / A_{\mathrm{f}}[-]$ & $\begin{array}{c}A_{\text {sol,sum }} / A_{\mathrm{f}}<\left(A_{\text {sol,sum }} / A_{\mathrm{f}}\right)_{\text {limit }} \\
\text { (depending on the building category) }\end{array}$ \\
\hline$\eta_{\mathrm{H}}[-]$ & $\eta_{\mathrm{H}}>\eta_{\mathrm{H}, \text { limit }}($ reference building $)$ \\
\hline$\eta_{\mathrm{W}}[-]$ & $\eta_{\mathrm{W}}>\eta_{\mathrm{W}, \text { limit }}($ reference building $)$ \\
\hline$\eta_{\mathrm{C}}[-]$ & $\eta_{\mathrm{C}}>\eta_{\mathrm{C}, \text { limit }}$ (reference building) \\
\hline$E P_{\mathrm{H}, \mathrm{nd}}\left[\mathrm{kWh} / \mathrm{m}^{2}\right]$ & $\begin{array}{c}E P_{\mathrm{H}, \mathrm{nd}}<E P_{\mathrm{H}, \mathrm{nd}, \text { limit(2019/21) }} \\
\text { (reference building) }\end{array}$ \\
\hline$E P_{\mathrm{C}, \mathrm{nd}}\left[\mathrm{kWh} / \mathrm{m}^{2}\right]$ & $\begin{array}{c}E P_{\mathrm{C}, \text { nd }}<E P_{\mathrm{C}, \text { nd,limit(2019/21) }} \\
\text { (reference building) }\end{array}$ \\
\hline $\begin{array}{c}E P_{\text {gl,tot }}\left[\mathrm{kWh} / \mathrm{m}^{2}\right] \\
\text { For residential } \\
\text { buildings: } \\
E P_{\text {gl,tot }}=\mathrm{EP}_{\mathrm{H}}+ \\
\mathrm{EP}_{\mathrm{W}}+\mathrm{EP}_{\mathrm{V}}+\mathrm{EP}_{\mathrm{C}}\end{array}$ & $E P_{\text {gl,tot }}<E P_{\text {gl,tot,limit(2019/21) }}$ \\
\hline
\end{tabular}

Furthermore, with the exception of buildings connected to a district heating network that covers the entire 
heating and DHW energy needs, the following use of renewable energy sources must be ensured: a minimum Renewable Energy Ratio (RER) for heating, cooling and DHW production equal to $50 \%$, a minimum RER for DHW production equal to $50 \%$, and a minimum electrical power $[\mathrm{kW}]$ powered by renewable energy sources $[\mathrm{kW}]$ equal to $1 / 50$ of the building footprint $\left[\mathrm{m}^{2}\right]$.

\section{Aims of the research}

The performed activities concerned the detailed energy audit of a building, located in the province of Turin, representative of the local residential building stock. The energy simulations were performed with the software DesignBuilder, which is an interface of EnergyPlus.

The aim was to identify energy retrofit interventions framed in a major renovation of the building, in compliance with the current legislative provisions. The energy refurbishment solutions have to comply both with the requirements of the I.D. June $26^{\text {th }}, 2015$ and with economic feasibility. This second aspect was investigated through a cost-optimal analysis, combined with a detailed building energy simulation, with a 30 years calculation period.

In the present work, the considered packages of energy refurbishment measures guarantee that:

- the energy performance index $(E P)$, expressed in $\mathrm{kWh} / \mathrm{m}^{2}$, is lower than that determined with the costoptimal methodology (Corrado et al., 2013);

- the difference in global cost $(\triangle G C)$ between the building after the various energy refurbishment measures and at the present state is negative;

- all the energy performance requirements defined at national level for a nZEB building are met (Table 1).

Therefore, two different intervention configurations were identified: the cost-optimal solution (minimisation of the costs), and the nZEB solution (increased levels of thermal performance and greater exploitation of renewable energy sources).

\section{Methods}

\section{Building energy audit}

The detailed energy audit was performed in accordance with EN 16247 parts 1-3, as described in Corrado et al. (2017).

In the pre-retrofit phase, the building is analysed in its current state and two different energy assessments are performed (as defined in EN ISO 52000-1): the Operational Energy Performance Assessment (OEPA), and the Tailored Energy Performance Assessment (TEPA). The former is based on the current building energy consumption, while the latter is carried out through dynamic simulations assuming the real climatic data and the actual users behaviour. The results of the two energy performance assessments are then compared, to calibrate the model. Calibration and evaluation of its accuracy (through statistical indices) are carried out according to ASHRAE Guideline 14 (2014). Starting from the calibrated model, a further energy assessment step is performed, defined as Calibrated Tailored Energy Performance Assessment (CTEPA), characterized by actual user data and standard climatic data, so as to make the subsequent analyses independent from the particular climatic conditions that occurred in a specific year.

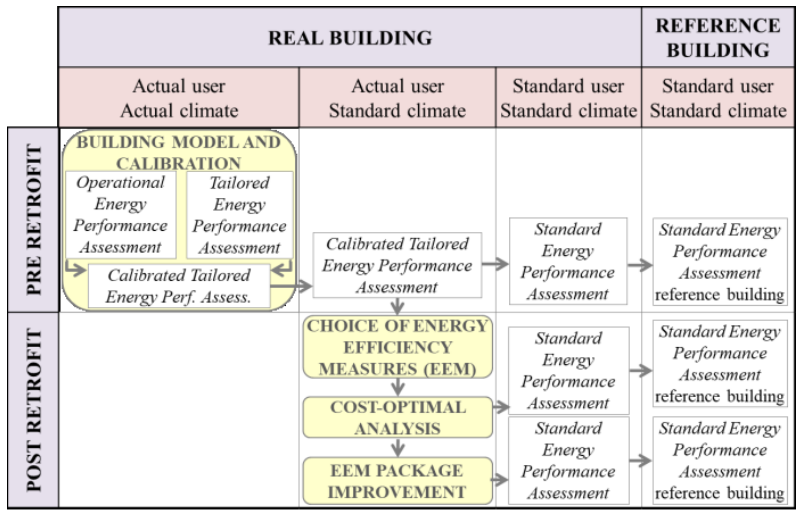

Figure 1: Detailed energy audit procedure.

The post-retrofit phase includes energy and economic analyses aimed at studying the effect of possible energy efficiency measures. For each selected configuration, the energy class is determined, through a Standard Energy Performance Assessment (SEPA), by applying the notional reference building approach, in compliance with the I.D. June $26^{\text {th }}, 2015$.

The verification of the minimum energy performance requirements at the national level was carried out in accordance with UNI/TS 11300-5. In accordance with ISO 52000-1, the building's energy performance is defined in terms of non-renewable primary energy $\left(E P_{\text {nren }}\right)$ and Renewable Energy Ratio $(R E R)$. The primary energy conversion factors, applied to the supplied energy, are obtained from the I.D. June $26^{\text {th }}$, 2015, while the ISO 52000-1 standard provides the $\mathrm{CO}_{2}$ production factors.

The input data relating to building and technical building systems required for the energy simulations were obtained from technical documentations and on-site inspections. The hourly real weather data were provided by ARPA Piemonte, while the hourly standard climate data were developed by the Italian Thermo-technical Committee (CTI).

\section{Cost-optimal analysis}

The economic evaluation was based on the global cost calculation, as specified by the EN 15459 standard. The identification of the cost-optimal energy efficiency measures was carried out by means of a sequential search-optimisation technique, based on the optimization algorithm NSGA-II (Elitist Non-Dominated Sorting Genetic Algorithm), as described in Corrado et al. (2014).

For the assessment of the global cost the following assumptions were used:

- calculation period of 30 years;

- energy costs, maintenance costs, and replacement costs (after 15 years for generation and emission 
systems, and after 10 years for windows) were considered;

- real interest rate of $4 \%$, and VAT of $22 \%$;

- costs of electricity and natural gas supplied by the Italian Regulatory Authority for Energy, Networks and Environment (ARERA);

- annual maintenance costs varying from $0 \%$ to $4 \%$ of the investment cost, depending on the technology;

- the service life of the construction elements was set at 20 years, while for the plants the service life was variable between 15 and 20 years.

The costs of the energy efficiency measures were derived from market surveys.

\section{Case study}

The selected case study (Figure 2) is a social housing building, located in the suburbs of Torino (north of Italy), in the climatic zone $\mathrm{E}\left(2100{ }^{\circ} \mathrm{C} \cdot \mathrm{d}<\mathrm{HDD} \leq 3000\right.$ ${ }^{\circ} \mathrm{C} \cdot \mathrm{d}$ ), built between the end of the eighties and the beginning of the nineties. This building is representative of a large number of buildings that, although built after the first laws on energy saving, have some hygrothermal critical issues (such as discontinuity of the insulating layer, mould problems in correspondence of thermal bridges, etc.).

The load-bearing structure is made up of reinforced concrete pillars, coupled with external cavity wall insulated with $4 \mathrm{~cm}$ of expanded polystyrene (EPS).

a)
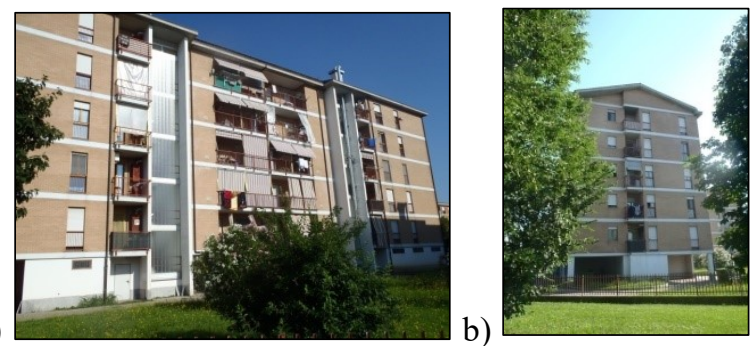

Figure 2: Building façades. a) East; b) North.

The building consists of six floors above ground (the first is the not inhabited entrance), plus a non-habitable attic floor. There is no basement, the lower floor of the building is a slab on grade, while part of the floor between the first and second floor above ground is exposed to the external environment (cantilevered slab).

Table 2 summarises the main geometric characteristics of the building.

Table 2: Main building geometrical data.

\begin{tabular}{|c|c|c|c|}
\hline Characteristic & Symbol & M.U. & Value \\
\hline Gross heated volume & $V_{\mathrm{g}}$ & $\mathrm{m}^{3}$ & 5967 \\
\hline Net floor surface & $A_{\mathrm{f}}$ & $\mathrm{m}^{2}$ & 2166 \\
\hline Opaque envelope surface & $A_{\mathrm{op}}$ & $\mathrm{m}^{2}$ & 1966 \\
\hline Windows surface & $A_{\mathrm{w}}$ & $\mathrm{m}^{2}$ & 247 \\
\hline Building compactness ratio & $S / V$ & $\mathrm{~m}^{-1}$ & 0.33 \\
\hline
\end{tabular}

The information obtained from the technical documentation relating to the opaque and transparent envelope components were verified through in situ inspections. The thermal properties of the envelope components are summarised in Table 3.
Table 3: Main building thermal performances.

\begin{tabular}{|c|c|c|c|}
\hline Parameter & Symbol & M.U. & Value \\
\hline Vertical opaque envelope $U$-value & $U_{\text {op }}$ & $\mathrm{W} / \mathrm{m}^{2} \mathrm{~K}$ & 0.45 \\
\hline $\begin{array}{c}\text { Vertical opaque envelope } \\
U \text {-value (ground floor) }\end{array}$ & $U_{\text {op, g }}$ & $\mathrm{W} / \mathrm{m}^{2} \mathrm{~K}$ & 1.70 \\
\hline Windows $U$-value (average) & $U_{\mathrm{w}}$ & $\mathrm{W} / \mathrm{m}^{2} \mathrm{~K}$ & 3.17 \\
\hline Stairs windows $U$-value & $U_{\mathrm{w}, \mathrm{s}}$ & $\mathrm{W} / \mathrm{m}^{2} \mathrm{~K}$ & 5.06 \\
\hline Upper slab $U$-value & $U_{\text {s.u }}$ & $\mathrm{W} / \mathrm{m}^{2} \mathrm{~K}$ & 0.80 \\
\hline Lower slab $U$-value & $U_{\mathrm{s}, 1}$ & $\mathrm{~W} / \mathrm{m}^{2} \mathrm{~K}$ & 0.71 \\
\hline Intermediate slab $U$-value & $U_{\mathrm{s}}$ & $\mathrm{W} / \mathrm{m}^{2} \mathrm{~K}$ & 1.47 \\
\hline Roof $U$-value & $U_{\mathrm{r}}$ & $\mathrm{W} / \mathrm{m}^{2} \mathrm{~K}$ & 1.93 \\
\hline Boiler efficiency & $\eta$ & $\%$ & 91.4 \\
\hline
\end{tabular}

Each apartment is served by an independent system for the combined heat and DHW production. The boilers, fuelled by methane gas, have a useful thermal power of $23 \mathrm{~kW}$, and a useful efficiency declared by the technical data sheet equal to $91.4 \%$, at $100 \%$ of the rated heat output. The control of the heating system is managed by a room thermostat. The emitting terminals consist of radiators, installed on internal walls. The heating system operates continuously, with the set-back temperature set by the user.

Ventilation is ensured only by window opening and infiltration (absence of a mechanical ventilation system).

\section{Occupancy, energy consumption survey}

In order to create an accurate model of the building to perform the energy audits, it is necessary to establish the real user profiles. In this way, it is possible to evaluate the occupation factor correlated to the number of occupants, the actual hours of presence inside each apartment, the users habits that influence the energy behaviour of the building. A typical occupation profile concerning to the most common family typology, was defined on the basis of the collected data.

The building energy consumption during the analysed heating season $(2017 / 2018)$ was obtained from the bills collected during the inspections. The heating period for the climatic zone E, is fixed from October $15^{\text {th }}$ to April $15^{\text {th }}$. The energy consumptions were divided according to the final use (space heating, DHW and food cooking) and related to the HDD of the considered heating season (Table 4).

Table 4: Measured energy consumption.

\begin{tabular}{|c|c|c|c|c|}
\hline Period & Total & $\begin{array}{c}\text { DHW } \\
\text { and } \\
\text { cooking } \\
{[\mathrm{kWh}]}\end{array}$ & Heating & HDD \\
{$[\mathrm{kWh}]$} & {$\left[{ }^{\circ} \mathrm{C} \cdot \mathrm{d}\right]$} \\
\hline Oct19 - Dec15, 2017 & 2775 & 468 & 2307 & 717 \\
\hline Dec16 - Feb09, 2018 & 3379 & 448 & 2931 & 865 \\
\hline Feb10 - Apr19, 2018 & $3581^{*}$ & 448 & 3133 & 866 \\
\hline
\end{tabular}

\section{Modelling options}

The input data required for the development of the detailed dynamic simulation model are related to the climatic conditions, the geometrical and thermal characteristics of the building and the users behaviour.

The envelope components were defined as previously described (Table 3). The evaluation of thermal bridges 
on the façades was carried out using the indications provided by the thermal bridges abacus (Capozzoli et al., 2011).

Each apartment of the building was modelled as a single thermal zone. The internal gains were defined in accordance with the UNI/TS 11300-1 standard. The analysis was carried out on the reference apartment (second floor, north-west exposure), and then the value of the internal gains density was applied to all the thirty thermal zones, as no detailed information about the users habits for the whole building apartments was available.

The utilization profiles for windows and solar shading devices were obtained from the questionnaires submitted to users, by distinguishing between the living area and the sleeping area.

The natural ventilation rates are calculated from the wind speed, the pressure difference between the internal end the external environment, and the size of the openings (according to the EN 16798-7 standard).

The modelling of the heating system and DHW was carried out using the EnergyPlus option "HVAC detailed" method, with continuous operation. The nominal thermal efficiency value used is equal to 0.824 (evaluated in accordance with the DesignBuilder requirements). The thermostat set-point temperature is equal to $21^{\circ} \mathrm{C}$, while the set-back temperature is $18^{\circ} \mathrm{C}$.

\section{Energy Efficiency Measures (EEMs) and related costs}

The considered energy efficiency measures (EEMs) concern both the building envelope and the technical building systems, as required by the I.D. June $26^{\text {th }}, 2015$ for an first level major renovation, and are summarised in Table 5.

\section{Table 5: Energy Efficiency Measures (EEMs).}

\begin{tabular}{|c|c|c|c|}
\hline $\mathbf{n}^{\circ}$ & EEM & Parameter & M.U. \\
\hline 1 & Opaque envelope thermal insulation & $U_{\mathrm{op}}$ & $\mathrm{W} / \mathrm{m}^{2} \mathrm{~K}$ \\
\hline 2 & Upper slab insulation & $U_{\mathrm{s} . \mathrm{u}}$ & $\mathrm{W} / \mathrm{m}^{2} \mathrm{~K}$ \\
\hline 3 & Lower slab insulation & $U_{\mathrm{s}, 1}$ & $\mathrm{~W} / \mathrm{m}^{2} \mathrm{~K}$ \\
\hline 4 & $\begin{array}{c}\text { Windows replacement (apartments } \\
\text { and stairs) }\end{array}$ & $U_{\mathrm{w}} ; U_{\mathrm{w}, \mathrm{s}}$ & $\mathrm{W} / \mathrm{m}^{2} \mathrm{~K}$ \\
\hline 5 & Unmovable shading devices & $F_{\mathrm{sh}, \mathrm{ob}}$ & - \\
\hline 6 & $\begin{array}{c}\text { Heat generator replacement (heating } \\
\text { and DHW) }\end{array}$ & $\eta_{\mathrm{gn}, \mathrm{H}} ; C O P$ & - \\
\hline 7 & Solar collectors installation & $A_{\text {coll }}$ & $\mathrm{m}^{2}$ \\
\hline 8 & Photovoltaic panels installation & $W_{\mathrm{p}}$ & $\mathrm{kW}$ \\
\hline
\end{tabular}

For each EEM, from one to three different performance levels (Energy Efficiency Options - EEOs) were considered.

Among the technological solutions of the thermal energy generators, the following autonomous alternatives were considered: current boilers, condensing boilers, and heat pumps. The use of photovoltaic panels was considered only coupled with the replacement of the generator with heat pumps. The PV system was sized in accordance with the UNI/TS 11300-4 standard, while the DHW plant was sized as specified in MISE (2018).

The values of the energy performance parameters and of the respective costs of each EEM are shown in Table 6.
Table 6: Energy Efficiency Options (EEOs) and costs.

\begin{tabular}{|c|c|c|c|c|}
\hline \multirow{2}{*}{$\begin{array}{c}\mathbf{n}^{\circ} \\
\text { EEM }\end{array}$} & \multirow{2}{*}{$\begin{array}{c}\text { Parameter; } \\
\text { Cost }\end{array}$} & \multicolumn{3}{|c|}{ EEO } \\
\hline & & 1 & 2 & 3 \\
\hline \multirow{2}{*}{1} & $U_{\mathrm{op}}\left[\mathrm{W} / \mathrm{m}^{2} \mathrm{~K}\right]$ & \multirow{2}{*}{$\mathrm{CB}$} & 0.29 & 0.25 \\
\hline & $C / A_{\mathrm{f}, \mathrm{n}}\left[€ / \mathrm{m}^{2}\right]$ & & 93.06 & 98.04 \\
\hline \multirow{2}{*}{2} & $U_{\text {s.u }}\left[\mathrm{W} / \mathrm{m}^{2} \mathrm{~K}\right]$ & \multirow{2}{*}{$\mathrm{CB}$} & 0.26 & 0.24 \\
\hline & $C / A_{\mathrm{f}, \mathrm{n}}\left[€ / \mathrm{m}^{2}\right]$ & & 9.31 & 9.96 \\
\hline \multirow{2}{*}{3} & $U_{\mathrm{s}, 1}\left[\mathrm{~W} / \mathrm{m}^{2} \mathrm{~K}\right]$ & \multirow{2}{*}{$\mathrm{CB}$} & 0.29 & 0.26 \\
\hline & $C / A_{\mathrm{f}, \mathrm{n}}\left[€ / \mathrm{m}^{2}\right]$ & & 24.14 & 27.06 \\
\hline \multirow{4}{*}{4} & $U_{\mathrm{w}}\left[\mathrm{W} / \mathrm{m}^{2} \mathrm{~K}\right]$ & \multirow{2}{*}{$\mathrm{CB}$} & 1.8 & 1.4 \\
\hline & $C / A_{f, n}\left[€ / \mathrm{m}^{2}\right]$ & & 534 & 615 \\
\hline & $U_{\mathrm{w}, \mathrm{s}}\left[\mathrm{W} / \mathrm{m}^{2} \mathrm{~K}\right]$ & \multirow{2}{*}{ CB } & 2.8 & \\
\hline & $C / A_{\mathrm{f}, \mathrm{n}}\left[€ / \mathrm{m}^{2}\right]$ & & 337 & - \\
\hline \multirow{2}{*}{5} & $F_{\text {sh,ob }}[-]$ & \multirow{2}{*}{$\mathrm{CB}$} & 0.96 & 0.89 \\
\hline & $\mathrm{C} / \mathrm{A}_{\mathrm{f}, \mathrm{n}}\left[€ / \mathrm{m}^{2}\right]$ & & 15.09 & 18.29 \\
\hline \multirow{2}{*}{6} & $\eta_{\mathrm{gn}, \mathrm{H}} / C O P$ & \multirow{2}{*}{$\mathrm{CB}$} & 1 & 4.1 \\
\hline & $C[€]$ & & 70500 & 195000 \\
\hline \multirow{2}{*}{7} & $A_{\text {coil }}\left[\mathrm{m}^{2}\right]$ & \multirow{2}{*}{$\mathrm{CB}$} & 30 & 36 \\
\hline & $C[€]$ & & 24120 & 28944 \\
\hline \multirow{2}{*}{8} & $W_{\mathrm{p}}[\mathrm{kW}]$ & 10 & 12 & 14 \\
\hline & $C[€]$ & 12500 & 15000 & 17500 \\
\hline
\end{tabular}

The cost, defined as indicated in MISE (2018), includes the cost of the technology, its maintenance and possible replacement, the installation and the hypothetical disposal of the solution to the Current Building (CB). According on the EEM, They are expressed, either in $€ / \mathrm{m}^{2}\left(C / A_{\mathrm{f}, \mathrm{n}}\right)$ or in $€(C)$.

The interventions involving the insulation of the opaque envelope were subject to thermo-hygrometric verification, to exclude interstitial and superficial condensation. No condensation phenomena were observed.

\section{Results and discussion}

\section{Calibration of the energy model}

The objective of the calibration of the model is to match the delivered thermal energy resulting from the TEPA of the reference apartment, with the one obtained by the OEPA. The calibration was made through the adjustment of the following parameters (always in compliance with the indications of the real user):

- from March $15^{\text {th }}$ to April $15^{\text {th }}$ and from October $1^{\text {st }}$ to $15^{\text {th }}$ the opening time of the bedroom windows in the morning was increased to 1 hour and 15 minutes,

- the generation system efficiency was corrected considering the upper calorific power supplied by the company providing the methane gas $(\eta=0.807)$,

- the set-back temperature of the heating system was been increased by half a degree Celsius $\left(18.5^{\circ} \mathrm{C}\right)$, and

- the internal heat gains were reduced by $3 \%$.

Figure 3 shows the results of the calibration.

The quality of the calibration was verified, in accordance with the statistical indices, defined in ASHRAE (2014). 


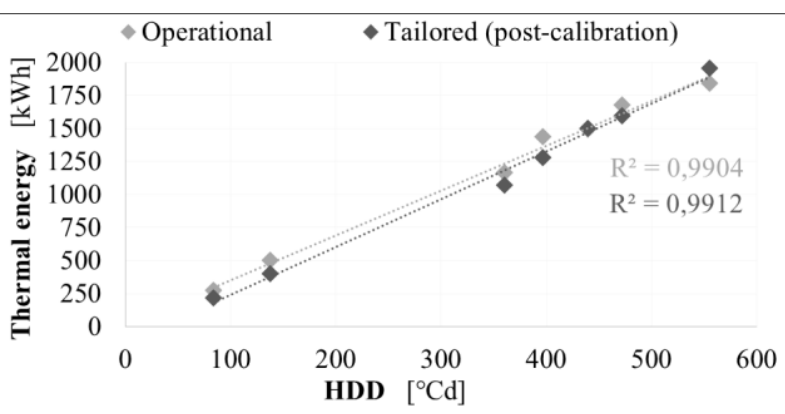

Figure 3: Comparison between the delivered thermal energy in relation to the HDD (OEPA and CTEPA).

\section{Building energy performance}

The CTEPA was then extended to the building level and performed using the standard climatic data of Torino. The energy performance indices at the building level are shown in Figure 4.

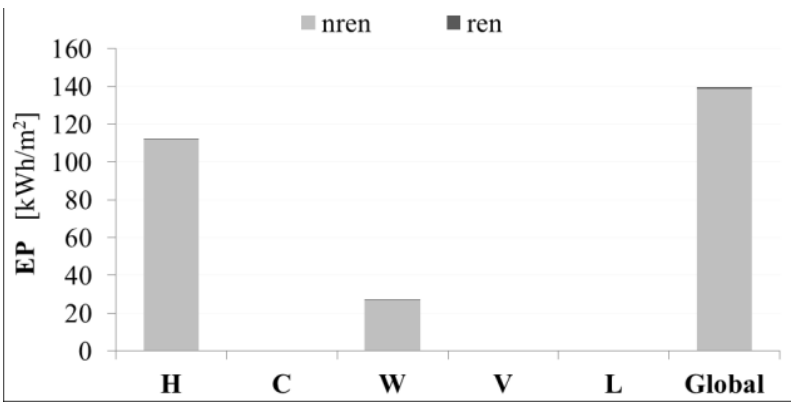

Figure 4: Building energy performance (CTEPA with standard climate data).

The obtained net energy need for space heating is equal to $57.6 \mathrm{kWh} / \mathrm{m}^{2}$, while for DHW production is 18.1 $\mathrm{kWh} / \mathrm{m}^{2}$. The total overall energy performance of the building (which is the ratio between the yearly primary energy use and the conditioned floor area) is about 140 $\mathrm{kWh} / \mathrm{m}^{2}$, and the related global cost over 30 years is 267 $€ / \mathrm{m}^{2}$. Through this energy assessment, the environmental impact of the building was been determined, in terms of annual $\mathrm{CO}_{2}$ emissions per unit of floor area, equal to $28.5 \mathrm{~kg} / \mathrm{m}^{2}$. According to the I.D. June $26^{\text {th }}$, for the energy classification of the simulated reference apartment, a standard energy rating (SER) was carried out by applying the technical specifications of the UNI/TS 11300 series. The SER considers both the standard climate and the standard user. Indeed, the reference apartment is classified as $\mathrm{D}$, with $101 \mathrm{kWh} / \mathrm{m}^{2}$ of yearly non-renewable primary energy use.

\section{Cost-optimal configuration}

Since the current building has already fairly good energy performances, almost all energy requalification measures entail excessively high costs compared to the energy savings that would result, especially if replacement of generation plants are supposed. For this reason, only the cost-optimal results obtained preserving the current generation system (traditional boiler) are shown, as they represent the interventions with higher technical and economic feasibility (Figure 5).

Table 7 summarises, for each EEM, the cost-optimal EEO (lowest value of $E P_{\mathrm{gl}, \text { nren }}$ in Figure 5).

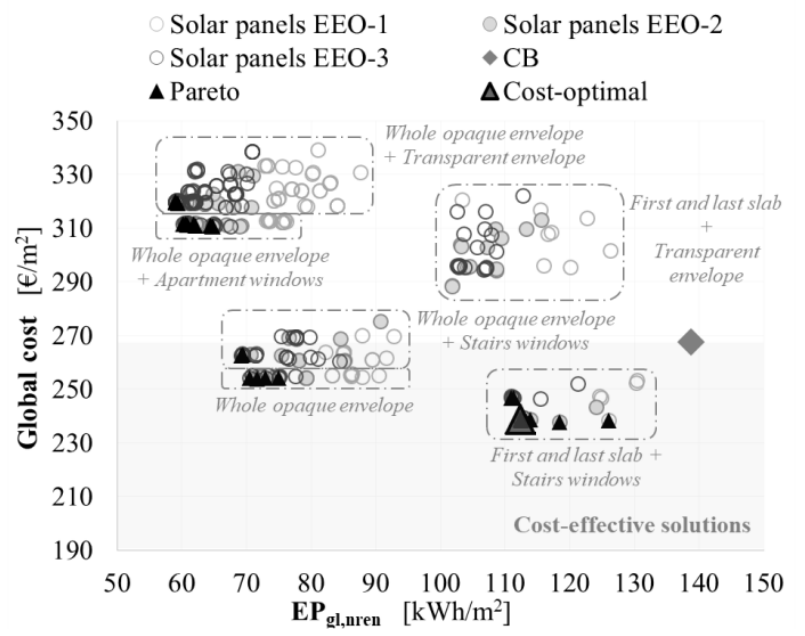

Figure 5: Cost-optimal analysis outputs.

Table 7: Cost-optimal configuration: EEM and EEO.

\begin{tabular}{|c|c|c|c|c|}
\hline \multirow{2}{*}{$\mathbf{n}^{\circ}$} & \multirow{2}{*}{ EEM } & \multirow{2}{*}{ Parameter } & \multicolumn{2}{|c|}{ EEO } \\
\cline { 4 - 5 } & Value & $\mathbf{n}^{\circ}$ \\
\hline 1 & $\begin{array}{c}\text { Opaque envelope } \\
\text { thermal insulation }\end{array}$ & $U_{\mathrm{op}}\left[\mathrm{W} / \mathrm{m}^{2} \mathrm{~K}\right]$ & $0.45^{*}$ & 1 \\
\hline 2 & Upper slab ins. & $U_{\mathrm{s} . \mathrm{u}}\left[\mathrm{W} / \mathrm{m}^{2} \mathrm{~K}\right]$ & 0.26 & 2 \\
\hline 3 & Lower slab ins. & $U_{\mathrm{s}, 1}\left[\mathrm{~W} / \mathrm{m}^{2} \mathrm{~K}\right]$ & 0.26 & 3 \\
\hline 4 & Windows replac. (flats) & $U_{\mathrm{w}, \mathrm{avg}}\left[\mathrm{W} / \mathrm{m}^{2} \mathrm{~K}\right]$ & $3.17^{*}$ & 1 \\
\cline { 2 - 5 } & Windows replac. (stairs) & $U_{\mathrm{w}, \mathrm{S}}\left[\mathrm{W} / \mathrm{m}^{2} \mathrm{~K}\right]$ & $5.06^{*}$ & 1 \\
\hline 5 & Unmovable shading & $F_{\text {sh.ob }}[-]$ & $1^{*}$ & 1 \\
\hline 7 & $\begin{array}{c}\text { Solar collectors } \\
\text { installation }\end{array}$ & $A_{\text {coil }}\left[\mathrm{m}^{2}\right]$ & 36 & 3 \\
\hline \multicolumn{4}{|l}{} \\
\hline
\end{tabular}

Considering a period of 30 years, the cost-optimal solution causes a global cost reduction of about $30 € / \mathrm{m}^{2}$, with an energy saving slightly lower than $20 \%\left(\triangle E P_{\mathrm{gl}, \text { nren }}\right.$ $=26.5 \mathrm{kWh} / \mathrm{m}^{2}$ ).

The energy performance indices at the building level of the cost-optimal solution are shown in Figure 6.

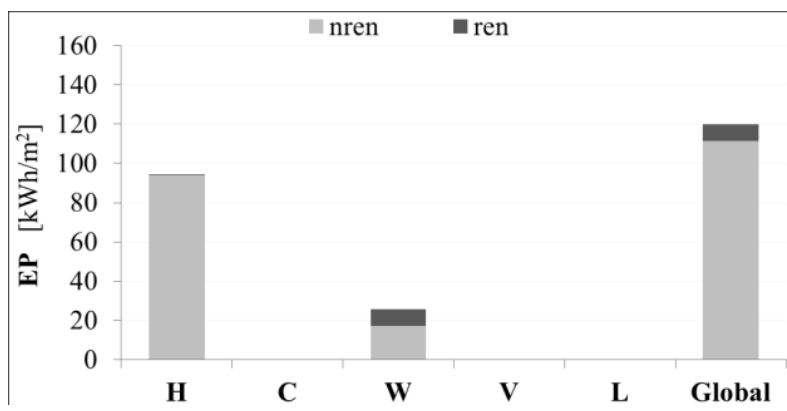

Figure 6: Cost-optimal energy performance (CTEPA with standard climate data).

The cost-optimal net energy need for the heating is equal to $50.1 \mathrm{kWh} / \mathrm{m}^{2}$, while for the DHW production remains $18.1 \mathrm{kWh} / \mathrm{m}^{2}$. The total overall energy performance of the building is about $120 \mathrm{kWh} / \mathrm{m}^{2}$, and the related global cost over 30 years is $240 € / \mathrm{m}^{2}$. The annual $\mathrm{CO}_{2}$ emissions per unit of floor area is equal to $23.0 \mathrm{~kg} / \mathrm{m}^{2}$.

Subsequently, a SER was performed, in order to calculate the cost-optimal energy performance indices in terms of primary energy. These indices were then compared with those obtained for the notional reference 
building, as required by the I.D. June $26^{\text {th }}, 2015$ (Table 8 ), which represent the limits that the analysed building must comply with. In Table 8 , the grey cells represent the energy performance indices which verify the limits imposed by the I.D. June $26^{\text {th }}, 2015$.

As for the current building (pre-retrofit), the energy classification of the reference apartment in the case of cost-optimal solution was evaluated, which appears to be in class $\mathrm{C}\left(E P_{\mathrm{gl}, \text { nren }}\right.$ equal to $\left.83.7 \mathrm{kWh} / \mathrm{m}^{2}\right)$.

Table 8: Cost-optimal configuration: energy performances indices and limits.

\begin{tabular}{|c|c|c|c|}
\hline Index & $\begin{array}{c}\text { Cost-optimal } \\
\text { building }\end{array}$ & $\begin{array}{c}\text { Limit } \\
\text { enforced } \\
\text { since 2015 }\end{array}$ & $\begin{array}{c}\text { Limit } \\
\text { enforced } \\
\text { since 2021 }\end{array}$ \\
\hline$H_{\mathrm{T}}\left[\mathrm{W} / \mathrm{m}^{2} \mathrm{~K}\right]$ & 0.84 & \multicolumn{2}{|c|}{0.75} \\
\hline$A_{\mathrm{sol}, \mathrm{sum}} / A_{\mathrm{f}}[-]$ & 0.04 & \multicolumn{2}{|c|}{0.04} \\
\hline$E P_{\mathrm{H}, \mathrm{nd}}\left[\mathrm{kWh} / \mathrm{m}^{2}\right]$ & 65.0 & 25.1 & 19.5 \\
\hline$E P_{\mathrm{gl}, \mathrm{tot}}\left[\mathrm{kWh} / \mathrm{m}^{2}\right]$ & 83.0 & 86.1 & 77.4 \\
\hline$\eta_{\mathrm{H}}[-]$ & 0.61 & 0.61 & 0.59 \\
\hline$\eta_{\mathrm{W}}[-]$ & 0.79 & 0.40 & 0.40 \\
\hline$R E R_{\mathrm{W}}[\%]$ & $54 \%$ & \multicolumn{3}{|c|}{$50 \%$} \\
\hline$R E R_{\mathrm{H}+\mathrm{C}+\mathrm{W}}[\%]$ & $12 \%$ & \multicolumn{3}{|c|}{$50 \%$} \\
\hline
\end{tabular}

\section{nZEB configuration}

For the nZEB configuration, an invertible heat pump was considered as a generation system (for heating, cooling and $\mathrm{DHW}$ ), with the consequent replacement of the current radiators with fan coils.

Table 9 shows for each EEM the EEO that allows to reach the nZEB target (compliance with the year 2021 limit values of the energy performance indices, determined for the reference building, as indicated in the I.D. June $\left.26^{\text {th }}, 2015\right)$.

Table 9: $n Z E B$ configuration: EEM and EEO.

\begin{tabular}{|c|c|c|c|c|}
\hline \multirow{2}{*}{$\mathbf{n}^{\circ}$} & \multirow{2}{*}{ EEM } & \multirow{2}{*}{ Parameter } & \multicolumn{2}{|c|}{ EEO } \\
\cline { 4 - 5 } & & Value & $\mathbf{n}^{\circ}$ \\
\hline 1 & $\begin{array}{c}\text { Opaque envelope } \\
\text { thermal insulation }\end{array}$ & $U_{\mathrm{op}}\left[\mathrm{W} / \mathrm{m}^{2} \mathrm{~K}\right]$ & 0.29 & 2 \\
\hline 2 & Upper slab ins. & $U_{\mathrm{s} . \mathrm{u}}\left[\mathrm{W} / \mathrm{m}^{2} \mathrm{~K}\right]$ & 0.24 & 3 \\
\hline 3 & Lower slab ins. & $U_{\mathrm{s}, 1}\left[\mathrm{~W} / \mathrm{m}^{2} \mathrm{~K}\right]$ & 0.26 & 3 \\
\hline \multirow{2}{*}{4} & $\begin{array}{c}\text { Windows replac. } \\
\text { (apartments) }\end{array}$ & $U_{\mathrm{w}}\left[\mathrm{W} / \mathrm{m}^{2} \mathrm{~K}\right]$ & 1.4 & 3 \\
\cline { 2 - 5 } & Windows replac. (stairs) & $U_{\mathrm{w}, \mathrm{s}}\left[\mathrm{W} / \mathrm{m}^{2} \mathrm{~K}\right]$ & 2.8 & 2 \\
\hline 5 & Unmovable shading & $F_{\text {sh,ob }}[-]$ & 0.89 & 3 \\
\hline 6 & Heat pump & $C O P[-]$ & 4.1 & 3 \\
\hline 7 & Solar collectors & $A_{\text {coil }}\left[\mathrm{m}^{2}\right]$ & 36 & 3 \\
\hline 8 & Photovoltaic panels & $W_{\mathrm{p}}[\mathrm{kW}]$ & 14 & 3 \\
\hline
\end{tabular}

The energy performance indices at the building level of the cost-optimal solution are shown in Figure 7.

The nZEB net energy need for the heating is equal to $32.7 \mathrm{kWh} / \mathrm{m}^{2}$, for the DHW production remains 18.1 $\mathrm{kWh} / \mathrm{m}^{2}$, and for the cooling is $14.3 \mathrm{kWh} / \mathrm{m}^{2}$. The total overall energy performance of the building is about 118 $\mathrm{kWh} / \mathrm{m}^{2}$. The nZEB solution determines an energy saving of about $54 \%$ compared to the cost-optimal solution, in terms of global non-renewable EP, against a total cost increase of about $275 € / \mathrm{m}^{2}$ (the nZEB solution cost is about $480 € / \mathrm{m}^{2}$ ). The nZEB annual $\mathrm{CO}_{2}$ emissions amount to about $9 \mathrm{~kg} / \mathrm{m}^{2}$ (less than half of the cost-optimal solution).

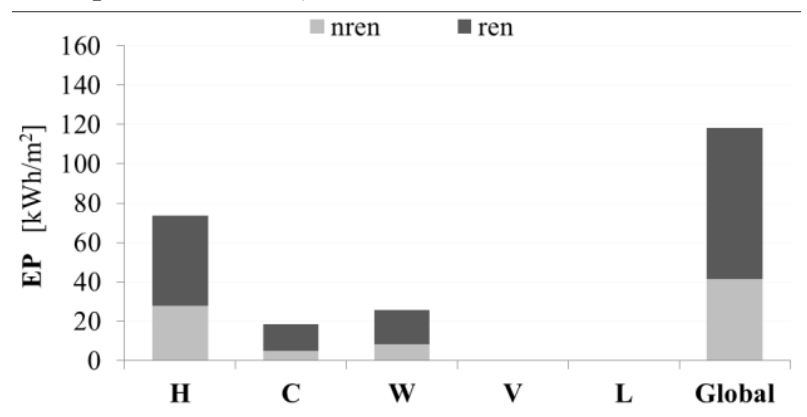

Figure 7: nZEB energy performance (CTER with standard climate data).

The comparison between the energy performance indices (primary energy) calculated using a standard user of the nZEB solution, and the legislative requirements (I.D. June $26^{\text {th }}, 2015$ ) is shown in Table 10 . A critical issue is represented by the verification of the $E P_{\mathrm{H}, \mathrm{nd}}$. This behaviour is, anyway, common for very thermally insulated buildings, where it is very difficult to simultaneously meet both the requirements on heating $\left(E P_{\mathrm{H}, \text { nd }}\right)$ and those on cooling $\left(E P_{\mathrm{C}, \text { nd }}\right)$ (Corrado et al., 2017 Report ENEA). The energy class for the nZEB reference apartment is $\mathrm{A} 2$ (with an $E P_{\mathrm{gl}, \text { nren }}$ equal to 45.3 $\mathrm{kWh} / \mathrm{m}^{2}$ ).

Table 10: nZEB configuration: energy performances indices and limits.

\begin{tabular}{|c|c|c|c|}
\hline Index & $\begin{array}{c}\text { nZEB } \\
\text { building }\end{array}$ & $\begin{array}{c}\text { Limit } \\
\text { enforced } \\
\text { since 2015 }\end{array}$ & $\begin{array}{c}\text { Limit } \\
\text { enforced } \\
\text { since 2021 }\end{array}$ \\
\hline$H_{\mathrm{T}}\left[\mathrm{W} / \mathrm{m}^{2} \mathrm{~K}\right]$ & 0.37 & \multicolumn{2}{|c|}{0.75} \\
\hline$A_{\mathrm{sol}, \mathrm{sum}} / A_{\mathrm{f}}[-]$ & 0.03 & \multicolumn{2}{|c|}{0.04} \\
\hline$E P_{\mathrm{H}, \mathrm{nd}}\left[\mathrm{kWh} / \mathrm{m}^{2}\right]$ & 21.0 & 25.7 & 19.6 \\
\hline$E P_{\mathrm{C}, \mathrm{nd}}\left[\mathrm{kWh} / \mathrm{m}^{2}\right]$ & 22.0 & 22.1 & 22.7 \\
\hline$E P_{\mathrm{gl}, \mathrm{tot}}\left[\mathrm{kWh} / \mathrm{m}^{2}\right]$ & 61.5 & 131.0 & 124.7 \\
\hline$\eta_{\mathrm{H}}[-]$ & 0.50 & 0.50 & 0.48 \\
\hline$\eta_{\mathrm{C}}[-]$ & 0.88 & 0.80 & 0.79 \\
\hline$\eta_{\mathrm{W}}[-]$ & 0.69 & 0.35 & 0.33 \\
\hline$R E R_{\mathrm{W}}[\%]$ & $51 \%$ & \multicolumn{3}{|c|}{$50 \%$} \\
\hline$R E R_{\mathrm{H}+\mathrm{C}+\mathrm{W}}[\%]$ & $74 \%$ & \multicolumn{3}{|c}{$50 \%$} \\
\hline
\end{tabular}

\section{Sensitivity analysis}

Through a sensitivity analysis, the influence of the individual EEM on the overall energy needs of the building was assessed (in terms of $E P_{\mathrm{gl}}$ ). The following EEMs were considered:

- insulation of the first and the last slabs (levels EEO2 and EEO3);

- energy refurbishment of the whole opaque building envelope, which means the vertical envelope, and the first and the last slabs (levels EEO2 and EEO3);

- use of solar panels (levels EEO2 and EEO3);

- replacement of the generation system with a gas condensing boiler.

The results are shown in Figure 8, where, for each case analysed, the values of the non-renewable overall EP, is compared to the renewable overall EP; the percentage is the $E P_{\mathrm{gl}, \mathrm{nren}}$ variation compared to the $\mathrm{CB}$ condition. 


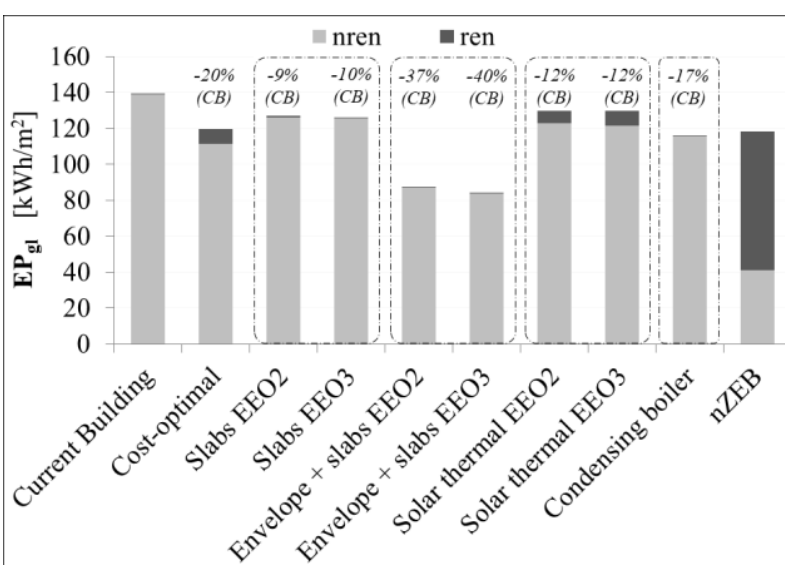

Figure 8: $E P_{\text {gl,tot }}$ obtained from the sensitivity analysis for each type of intervention.

The intervention on the slabs reduces the non-renewable primary energy use of about $10 \%$, compared to the CB. If combined with the insulation of the vertical opaque envelope, this reduction reaches $37 \%$ and $40 \%$, for the minimum performance level required in 2015 and 2021, respectively. With only the solar thermal intervention, the savings on $E P_{\text {gl,nren }}$ is approximately $12 \%$ (for both EE2 and EE3). Moreover, the use of condensing boilers would lead to a reduction of $17 \%$ in the non-renewable primary energy needs.

The nZEB solution is not directly comparable with the others, as the energy needs are also affected by the summer cooling. Indeed, the data related to heating and DHW production were separated from those for cooling. The $E P_{\mathrm{H}+\mathrm{W}}$ of the nZEB solution is significantly lower than both the $\mathrm{CB}$ and the cost-optimal solution. In particular, the $E P_{\text {gl,nren }}$ decreases respectively by $74 \%$ and $67 \%$, with a use of renewable energies almost eight times higher than in the cost-optimal solution (due to the presence of both solar thermal and photovoltaic system).

Figure 9 shows the global costs of all the analysed EEMs, divided into investment costs, maintenance and management costs, and energy costs. The percentages in the figure refer to the change in global cost compared to the current building $(*$ in the case of the nZEB solution, the percentage refers to the global cost, excluding the energy cost for summer cooling). The energy cost of the nZEB solution is influenced by the contribution for summer cooling, although it is in any case extremely low, compared to the current situation. This contribution is equal to about $17 \%$ of the total energy cost (black coloured in Figure 9). The energy cost savings obtained, however, are thwarted by the very high investment cost.

For all the analysed measures, while the global cost is slightly reduced (between $5 \%$, for interventions on the opaque envelope and slabs, and $11 \%$, in the case of intervention only on the slabs), the individual cost items are significantly variable (in particular, the investment and the energy costs). For example, in the case of the entire opaque envelope insulation, the energy cost is considerably reduced, almost $40 \%$, while the investment cost is significantly higher than all other single measures considered.

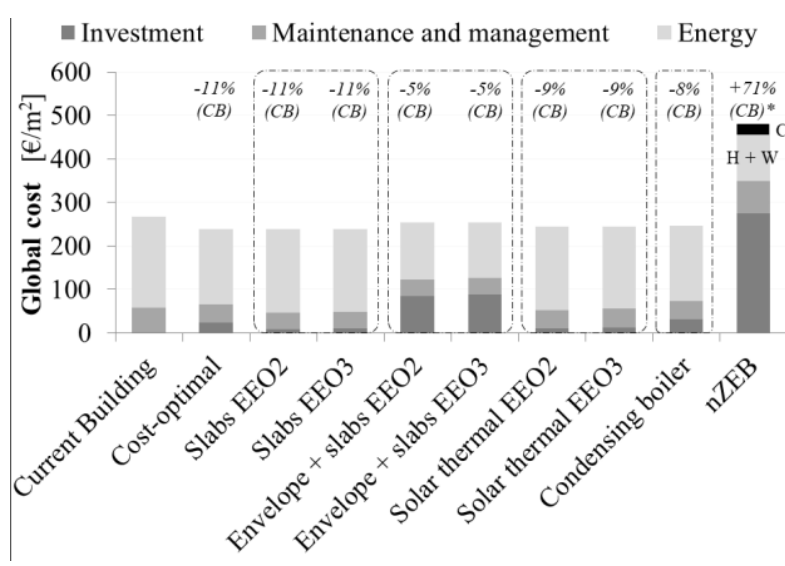

Figure 9: Global Costs obtained from the sensitivity analysis for each type of intervention.

\section{Conclusions}

The research activity concerned the energy audit of a building located in the province of Torino, representative of the residential building stock in the climate zone E. The aim was to identify energy retrofit interventions framed in a major building energy renovation, complying with the current legislative provisions (I.D. June $26^{\text {th }}$, 2015). This was pursued through an innovative analysis methodology, based on detailed dynamic simulations, model calibration and associated cost-optimization of the supposed Energy Efficiency Measures (EEMs). The EEMs were, indeed, selected to identify the refurbishment solution characterised by the lowest global cost over a period of 30 years (costoptimal solution). It was observed that this solution didn't meet the nZEB requirements. Therefore, a new configuration, characterised by the highest levels of Energy Efficiency Options of the involved EEM (except for the insulation of the opaque envelope), and able to exploit more renewable resources, was selected. The so identified nZEB solution allows a halving of the energy consumption in terms of $E P_{\mathrm{gl}, \text { nren, }}$, compared to the costoptimal solution, but causes almost a doubling of the total investment cost, compared to the current building (excluding the summer period energy costs).

Finally, through a sensitivity analysis, it was demonstrated that the interventions that involve greater exploitation of renewable sources are those that allow greater energy savings, second only to the whole opaque envelope insulation (which required a significant initial investment cost).

The use of dynamic simulation for cost-optimal analysis is an advanced and not common approach, which requires particular attention in the programming phase of the simulations, and in the definition of the input data. For example, the number of simulation runs (and, consequently, the required time for each optimization) is strongly influenced by the complexity of the model. Also the cost evaluation requires some assumptions and simplifications. Therefore, to maximize the potential of this approach, which allows simulating very accurately the actual building energy behaviour, it is fundamental to 
carefully evaluate all the critical issues that can be met, especially in the case of large and complex models.

\section{Acknowledgement}

The research was developed in the framework of a cooperation agreement between Politecnico di Torino and the Italian National Agency for New Technologies, Energy and Sustainable Economic Development (ENEA), under a program agreement between ENEA and the Italian Ministry of Economic Development (Implementation Plan 2017, project title: "Riqualificazione energetica degli edifici pubblici esistenti: direzione $n Z E B$. Studio di un edificio di edilizia residenziale pubblica di riferimento nella zona climatica Nord Italia (zona E: $2.100<G G \leq 3.000$ )"). Thanks also to the Territorial Agency for the House of Central Piedmont (ATC) for the supply of the case study data.

\section{Nomenclature}

$\begin{array}{lll}\text { Symbol } & \text { Quantity } & \text { Unit } \\ A & \text { Area } & {\left[\mathrm{m}^{2}\right]} \\ C O P & \text { Coefficient of performance } & {[-]} \\ E P & \text { Energy performance index } & {\left[\mathrm{kWh} / \mathrm{m}^{2}\right]} \\ F_{s h} & \text { Shading factor } & {[-]} \\ G C & \text { Global cost } & {[€]} \\ H & \text { Mean overall heat transfer coefficient } & {\left[\mathrm{W} / \mathrm{m}^{2} \mathrm{~K}\right]} \\ R E R & \text { Renewable energy ratio } & {[-]} \\ S / V & \text { Compactness ratio } & {[1 / \mathrm{m}]} \\ U & \text { Thermal transmittance } & {\left[\mathrm{W} / \mathrm{m}^{2} \mathrm{~K}\right]} \\ V & \text { Volume } & {\left[\mathrm{m}^{3}\right]} \\ W & \text { Power } & {[\mathrm{W}]} \\ \eta & \text { Efficiency } & {[-]}\end{array}$

\section{References}

American Society for Heating Refrigerating Airconditioning Engineers (2014). Guideline 14 Measurement of Energy, Demand, and Water Savings.

Ascione, F., Bianco, N., De Stasio, C., Mauro, G.M., Vanoli, G.P. (2015). A new methodology for costoptimal analysis by means of the multi-objective optimization of building energy performance. Energy and Buildings 88, 78-90.

Capozzoli, A., Corrado, V., Gorrino, A., Soma, P. (2011). Atlante nazionale dei ponti termici. Edizione Edilclima.

Corrado, V., Ballarini, I. (2016). L'avanzamento della riqualificazione energetica del patrimonio edilizio residenziale regionale (Regione Piemonte, IT). EPISCOPE project.

Corrado, V., Ballarini, I., Paduos, S., Tulipano L. (2017). A new procedure of energy audit and cost analysis for the transformation of a school into a nearly zeroenergy building. Energy Procedia 140, 325-338.

Corrado, V., Ballarini, I., Paduos, S. (2014). Assessment of cost-optimal energy performance requirements for the Italian residential building stock. Energy Procedia 45, 443-452.
Corrado, V., Ballarini, I., De Luca, G., Primo, E. (2017). Riqualificazione energetica degli edifici pubblici esistenti: direzione nZEB. Studio dell'edificio di riferimento uso uffici della PA nella zona climatica Nord Italia (zona E: $2.100<\mathrm{GG} \leq 3.000$ ). (In italian).

CRESME, RIUSO03 (2014) Ristrutturazione edilizia, riqualificazione energetica, rigenerazione urbana. (In italian).

Dalla Mora, T., Peron, F., Romagnoni, P., Almeida, M., Ferreira, M. (2018). Tools and procedures to support decision making for cost-effective energy and carbon emissions optimization in building renovation. Energy and Buildings 167, 200-215.

Dodoo, A., Gustavsson, L., Tettey, U.Y.A (2017). Final energy savings and cost-effectiveness of deep energy renovation of a multi-storey residential building. Energy 135, 563-576.

EEAP (2014). Italian Energy Efficiency Action Plan https://ec.europa.eu/energy/sites/ener/files/documents /2014_neeap_en_italy.pdf.

European Committee for Standardisation (2018). Energy performance of buildings - Overarching EPB assessment - Part 1: General framework and procedures (EN ISO 52000-1).

European Committee for Standardisation (2018). Energy performance of buildings - Economic evaluation procedure for energy systems in buildings - Part 1: Calculation procedures, Module M1-14 (EN 154591).

European committee for Standardisation (2017). Energy performance of buildings - Ventilation for buildings Part 7: Calculation methods for the determination of air flow rates in buildings including infiltration (Modules M5-5) (EN 16798-7).

Eurostat statistics (Last access: 25/09/2018) https:/ec.europa.eu/eurostat/data/database

Italian Ministry of Economic Development. (2015) Interministerial Decree 26/06/2015. Applicazione delle metodologie di calcolo delle prestazioni energetiche e definizione delle prescrizioni e dei requisiti minimi degli edifici. Official Journal of the Italian Republic, July $15^{\text {th }} 2015$. (In Italian).

Italian National Organisation for Standardisation (20102016). Energy performance of buildings (UNI/TS 11300 series). (In Italian).

Italian Ministry of Economic Development - MISE (2018). Applicazione della metodologia di calcolo dei livelli ottimali in funzione dei costi per i requisiti minimi di prestazione energetica (Direttiva 2010/31/UE Art. 5). (In Italian. In press).

Rhodes, J.D., Gorman, W.H., Upshaw, C.R., Webber, M.E. (2015). Using BEopt (EnergyPlus) with energy audits and surveys to predict actual residential energy usage. Energy and Buildings 86, 808-816. 